\title{
Health education and teaching innovation at the university: Experience with students of social sciences
}

\author{
Encarnación Pedrero-García ${ }^{\mathrm{a}}$ \\ ${ }^{a}$ Facultad de Ciencias Sociales, Universidad Pablo de Olavide, Crta. De Utrera, Km.1 Seville, ES- \\ 41013, Spain
}

\begin{abstract}
The objective of this paper is to show how health education can be introduced transversally in the university to improve the quality of life of students. Through a teaching innovation project, we have incorporated a meeting point to educate and inform about health education, involving 180 students from the social education degree at the Pablo de Olavide University (Seville, Spain). The methodology followed is quantitative using an ex professo script and analyzing the data with the SPSS software in order to measure the satisfaction degree of student with respect to 5 variables: usefulness, methodology, organization and resources, teaching staff and general satisfaction. The results show that the majority of students are satisfied with the inclusion of health education related topics.
\end{abstract}

\section{Introduction}

The teaching team of this project has consolidated, through a decade of continuous work in the field, a strategic line on Education and Health Promotion (developed by the WHO in the Ottawa Charter, 1986), within the Pablo de Olavide University of Seville. This work has been carried out in four main areas:

-Teaching and training in undergraduate, master's, expert and university extension courses, as well as conferences and seminars such as: Education for Health and Quality of Life, Prevention of Drug Addiction and Addiction, Educational Action in Children and Youth, Sociocultural Animation and Community Development, Youth Mediators in Health Education, Prevention of psychosocial risks in adolescents and young people....

-Research: through different projects and studies on the prevalence, attitudes, patterns and motivations of the university population in relation to drug use, etc., from which a good number of papers have been published in indexed journals as well as books.

-Dissemination: through information and training activities on prevention and awareness campaigns aimed at the whole of the University Community, held on the commemorative days most closely related to healthy habits.

-Collaboration with other public and private bodies and institutions: Regional Ministries of Education, Health and Social Welfare of the Regional Government of Andalusia, Seville City Council, Dos Hermanas City Council, Proyecto Hombre, Fundación de Ayuda contra

${ }^{\mathrm{a} C}$ Corresponding author: epedgar@upo.es 
la Drogadicción, Reina Sofía Centre, ISTAS Foundation, National Institute for Health and Safety at Work...), in the establishment of agreements and projects for the dissemination and advancement of Health Education/Promotion.

In this same line of work, we consider it essential that at the Pablo de Olavide University of Seville, which is already part of the Spanish Network of Healthy Universities (www.unisaludables.es), as well as the Andalusian Network of Healthy Universities, a Youth Form point is created, which will contribute to our centre becoming a healthy space where young people can receive information and attention to help them decide on the healthiest answers (http://www.formajoven.org/).

The Forma Joven is a Youth Information and Training Program for adolescents and young people. It is constituted as a health strategy aimed at promoting healthy environments and behaviours among young people in Andalusia. The strategy consists of bringing health promotion and health risk prevention activities closer to the environments where young people live and give them an active and central role in these activities. It is based on intersectoral action and its development involves several Departments of the Andalusian Regional Government, as well as other institutions and social agents such as town halls, associations, etc. Thousands of students have participated in it since its development.

Forma Joven aims to train boys and girls to make the healthiest choices in terms of their lifestyles: nutrition, physical activity, sexuality, etc. and their psychological and social wellbeing, as well as in the prevention of accidents, smoking and other addictions. It takes place in the Youth Form Points, located in the various spaces frequented by the youth population, including the universities.

The creation of this point Forma Joven and its full integration into the University is carried out by involving students in three subjects of the Faculty of Social Sciences through the methodology of collaborative learning.

\section{Methodology}

We start from a methodology based on collaborative learning, which implies that students actively participate in a motivated and committed way in their own teaching-learning process, while developing basic professional skills.

For the development of the project we started by establishing the work teams, and within them, small groups in each of the subjects involved in the project. The small working groups are made up of a maximum of 4 people, promoting diversity within them and, if possible, a balance between the number of boys and girls in the group. The more talents, visions and different sensibilities we integrate into the project, the more enriching the experience will be.

The functioning of the groups is based on rules of dialogue as well as on the assignment of roles based on their motivations and abilities, which are given to them in writing in advance at the beginning of the semester. The philosophy of collaborative work implies that students must take responsibility for their own learning as well as the learning of the rest of the small group. This makes it easier for both the assignment of roles and the commitment and fulfilment of tasks to be managed by the students themselves. The number of participants in the project is approximately 200 students.

The task of the project's teaching staff is to guide them through each of the phases, but to allow them to assume maximum responsibility gradually, so that they can plan, organize and develop their own ideas.

The reason for choosing the methodology of collaborative learning is the flexibility it offers us as it allows us to work through project-based learning, webquests, flipped classroom, etc.... 
The students have the necessary time to generate ideas, discuss and contrast them, both in small groups and in the large group, encouraging them to participate in the decisionmaking process of the project in a group setting.

The project has been developed in 4 phases:

1) Creation of the point Forma Joven in the University.

2) Management and dissemination of the Youth Information Point among the university community.

3) Planning and execution of activities to be developed from the point of Youth Form based on the five areas of intervention: Emotional education, healthy lifestyles, sexuality and egalitarian relationships, positive use of ICT, consumption prevention.

4) Project Evaluation.

The actions and milestones developed in each phase are detailed below:

The first phase in which the Forma Joven point was created took place in September, with the beginning of the course.

During the month of October, the physical space and website of the Forma Joven was managed and disseminated through the social networks and posters distributed throughout the university.

During the months of November and December we worked with the group of the subject "Educational action in childhood and youth" (3rd double degree Social EducationSocial Work) in the planning of the activities to be developed from the Youth Form. The large group was divided into 15 small groups of 4 people. These groups chose the theme to work on within the 5 priority areas of Forma Joven: Emotional education, Healthy lifestyles, Sexuality and egalitarian relationships, Positive use of ICT, Consumption prevention. At the same time, actions were planned for December 1 (World AIDS Day) to spread and prevent the disease.

With the beginning of the second semester, we involved two new groups, students from the subjects "Sociocultural Animation" (4th of the double degree ES-TS) and "Health Education" (3rd ES). Following the methodology developed in the first semester of collaborative learning, the students were distributed in small groups and we began to carry out training for the university community. Workshops were held in February, March, April and May, as well as on 7 April (World Health Day) and 30 May (World No Tobacco Day).

\section{Research result}

The project will be evaluated in a processual way with the achievement of milestones that we establish in each of its 4 phases. In turn, the evaluation of students with respect to their participation in the project will be carried out through rubrics so that they can self-evaluate and evaluate the work done by their peers in the groups, in accordance with the methodology of collaborative learning. On the other hand, the teaching team will arrange individual and group interviews to follow up with the project participants. The interviews, together with the observation and the headings of the students will constitute the instruments of evaluation of the same one.

We believe that this teaching innovation project is a benefit for the entire University Pablo de Olavide, and not only for the participants in it, since by creating the youth information point we are influencing the improvement of the quality of life of the entire university community in the long term. The project aims to research, innovate, apply, train, and inform about healthy lifestyle habits using the collaborative learning methodology.

The innovation can be easily transferred, as the collaborative learning methodology can be replicated in any subject, subject or qualification. In addition, our priority objective is to provide an environment in which the students of the Faculty of Social Sciences can become 
professionals in the university, so we are promoting professional skills that they will need in the near future, while working collaboratively.

Results show that Forma Joven is a support tool for those promoting youth health and for the educational institution. Teachers coordinating the program are a crucial figure to promote health. Encouraging the participation and implication of students in the different activities is the key to the program success. The majority of students are satisfied with the inclusion of health education-related topics. The self-perception shown indicates that they find beneficial having knowledge and specific information about sexuality, addictions, emotional education and healthy habits, as they believe these are important topics for their personal and career development.

\section{Conclusion}

In conclusion, the program Forma Joven is an excellent strategy for the promotion of healthy contexts and behaviours among students and young people. It also encourages youth learning and the collaboration between the educational institution and healthcare community resources. Regarding the originality and value of the proposal, we think that teaching innovation projects where health education is integrated in order to improve the quality of life of students can hardly be found in our country.

The Forma Joven programme is a health strategy for adolescents and young people launched in 2001 by different Departments of the Regional Government of Andalusia, in who also collaborate with other institutions and agents social as city councils and/or mothers' associations and parents, who consider it objectives:

- Bringing the promotion closer from health to the places they frequent usually the boys and girls.

- Contribute to providing them with resources and capacities to deal with the risks.

- Encourage the possibility of combining health and fun.

- Encourage the choice of healthier behaviors.

It takes place preferably in schools in Andalusia, although it also takes place in other places frequented.

by this population as associations, leisure spaces or NGOs, among others.

By virtue of the pedagogical, organisational and managerial autonomy of educational establishments, they may choose to register for "Forma Joven" on a voluntary basis, making the application for participation. The development of the program responds to a project of action planned, carried out and evaluated by the Forma Joven Team. In this cooperation, professionals from the education, health and other sectors, such as education, health and of drug prevention.

For the Forma Joven Team to be constituted, it will always be a necessary condition for coordination between the centre and the health center. Almost $85 \%$ of the educational centres

states that there is a coordinated working relationship between the coordinating faculty and staff of the programme health professional, the telephone being the way of communication used by these professionals.

At the same time, communication and coordination with the persons involved in programme activities take place at the meetings of the Forma Joven Team. The usefulness of these meetings is rated with a score of average of more than 7 on a scale of 0 to 10 . The teaching staff coordinating the programme is a key figure in promoting health at this age by enabling a greater rapprochement with boys and girls. In this sense, all the agents surveyed assess the continuity of the programme in educational establishments with a score of "remarkable". In general, the areas of "Healthy Lifestyles" and "Sexuality and Relationships" are the most frequently addressed by young people. The activities 
corresponding to "Drug prevention and other addictions" are preferred. The Evaluation Study of the Youth Form Programme concludes that it is an excellent strategy for the promotion of contexts and healthy behaviors among young people, while also encouraging the learning of young people.

\section{References}

1. Bisquerra, A. R. (coord.). Educación emocional. Propuestas para educadores y familias. Bilbao: Desclée de Brower, (2011).

2. Bisquerra, A. R. Educación emocional y competencias básicas para la vida. Revista de Investigación Educativa, 21(1), 7-43, (2003).

3. Cobo Romaní, R. El concepto de tecnologías de la información. Benchmarking sobre las definiciones de las TIC en la sociedad del conocimiento. ZER: Revista de Estudios de Comunicación, Volumen 14 - Número 27, (2009).

4. O.M.S. Carta de Ottawa para la promoción de la salud. Conferencia internacional para la promoción de la salud. Ottawa: Asociación Canadiense de Salud Pública, (1986).

5. Martínez, A., Muñoz, M.C., Cobos, D. "Intervención educativa en socioadicciones y adicciones sin sustancia". En Educación para la salud y prevención de riesgos psicosociales en adolescentes y jóvenes" (181-198). Madrid: Narcea, (2017).

6. Morón, J.A, Pérez, I. y Pedrero, E. Educación para la Salud y prevención de los riesgos psicosociales: En adolescentes y jóvenes. Madrid: Narcea, (2017).

7. Morón, J.A. (2015). Investigar e intervenir en Educación para la Salud. Madrid: Narcea.

8. Pedrero, E. El Ámbito Preventivo en Drogodependencias: Revisando Programas de Promoción y Educación para la Salud. Actas del Congrés Internacional Virtual d'Educació CIVE 2010. Palma de Mallorca: Escola de formació en Mitjans Didàctics (STEI-i), (2010).

9. Pedrero, E. "Los modelos de educación afectivo-sexual en adolescentes y jóvenes". En Investigar e intervenir en Educación para la Salud (133-146). Madrid: Narcea, (2015). 